P. J. Stow MB bS FFARCS, F. A. Butrows MD FrCPC, M. E. McLeod MD FRCPC, J. G. Coles MD FrCSC

\title{
The effects of cardio- pulmonary bypass and profound hypothermic circulatory arrest on anterior fontanel pressure in infants
}

The Ladd transducer was used to measure anterior fontanel pressure in 23 infants undergoing cardiopuimonary bypass and profound hypothermic circulatory arrest for surgical correction of congenital heart disease. Mean ( \pm SD) minimum aesophageal and rectal temperatures of $11.3 \pm 1.5^{\circ} \mathrm{C}$ and $18.1 \pm 2.2^{\circ} \mathrm{C}$ respectively were achieved with a mean duration of arrest of 53.4 \pm 13.9 minutes. During reperfusion cardiopulmonary bypass after circulatory arrest, mean anterior fontanel pressure $(18.3 \pm 6.4 \mathrm{mmHg}$ ) increased above baseline pre-bypass. values $(10.6 \pm 2.9 \mathrm{mmHg})(p<0.005)$. Mean arterial blood pressure decreased significantly from pre-bypass values $(57.0 \pm 11.8$ mmHg) during both cooling ( $38.8 \pm 8.4 \mathrm{mmHg})$ and rewarming cardiopulmonary bypass $(45.8 \pm 8.9 \mathrm{mmHg})(p<0.005)$. These changes were associated with a significant decrease in cerebral perfiusion pressure during cooling (27.3 $\pm 11.0 \mathrm{mmHg})$ and rewarming cardiopulmonary bypass $(27.5 \pm 10.6 \mathrm{mmHg}$. compared with baseline pre-bypass values $(46.5 \pm 12.3 \mathrm{mmHg})$ $(p<0.005)$. The dato demonstrate significant but transient decreases in cerebral perfiesion pressure during cooling and re. warming bypass.

\section{Key words}

ANAESTHESIA, PAEDIATRIC: monitoring;

LADD TRANSDUCER: surgery, anterior fontanel pressure; TECHNIQUES: cardiopulmonary bypass.

From the Departments of Anaesthesia and Cardiovascular Surgery and the Research Institute, The Hospital for Sick Children, University of Toronto, Toronto, Ontario. Presented in part at the Annual Meeting of the American Society of Anesthesiologists, Las Vegas, October 1986.

Address correspondence to: Dr. F. A. Burrows, Department of Anaesthesia, The Hospital for Sick Children, 555 University Avenue, Toronto, Ontario, M5G IX8.
Studies in adults have demonstrated significant decreases in cerebral perfusion pressure (CPP) during cardiopulmonary bypass (CPB) ${ }^{1-4}$ Similar data in infants undergoing $C P D$ with profound hypothermic circulatory arrest (PHCA) are lacking. Inadequate CPP during CPB may be associated with postoperative neurological deficit, and a knowledge of changes in perfusion pressure is important for the management of these infants.

Mean arterial blood pressure alone is a poor indicator of CPP, ${ }^{1}$ which is defined as mean arterial blood pressurc minus intracranial pressure (MAP - ICP). Intracranial pressure in the infant can be estimated noninvasively using the Ladd transducer to measure anterior fontanel pressure. This device consists of a pressure sensitive membrane on which is mounted a mirror, a fibreoptic light source and a pneumatic system. Distortion of the membrane by a change in pressure alters the reflection of light back to the monitor which responds by altering the air pressurc in the system to equalize pressures across the membrane. The pressure required to balance the system is constantly displayed on the monitor as anterior fontanel pressure. ${ }^{5}$ Although affected by application pressure, the measured anterior fontanel pressure (AFP) correlates well with intracranial pressure (ICP) in infants. ${ }^{6}$

\section{Methods}

With the approval of the Human Subject Review Committee, 23 infants ( $<10$ months of age) admitted to The Hospital for Sick Children for surgical repair of congenital cardiac defects requiring cardiopulmonary bypass and profound hypothermic circulatory arrest were studied. Infants over the age of ten months, who may have a fibrous anterior fontanel, were excluded. Premedication of intramuscular atropine $20 \mu \mathrm{g} \cdot \mathrm{kg}^{-1}$ was administered $30-60$ minutes preoperatively. On arrival in the operating room, the hair over the anterior fontanel was shaved and tincture of benzoin was applied to the scalp. Following calibration of the Ladd transducer and single-channel 
chart recorder, the transducer was laid over the fontanel and held in place using a $3 \mathrm{~cm}$ by $3 \mathrm{~cm}$ piece of adhesive foam (3M Canada Inc., North York, Ontario). Excessive application pressure was avoided and the response to Queckenstedt's manoeuvre noted. ${ }^{7}$ Intravenous access and routine monitoring (electrocardiograph, doppler pulse monitor, sphygmomanometer cuff, pulse oximeter and precordial stethoscope) were established.

Infants were anaesthetized according to the preference of the anaesthetist, by intravenous induction with fentanyl $10-30 \mu \mathrm{g} \cdot \mathrm{kg}^{-1}(\mathrm{n}=17)$ or morphine $2 \mathrm{mg} \cdot \mathrm{kg}^{-1}(\mathrm{n}=2)$, by inhalational induction with halothane $(n=1)$ or isoflurane $(n=1)$, or by intramuscular ketamine $10 \mathrm{mg}$. $\mathrm{kg}^{-1}(\mathbf{n}=2)$. Neuromuscular blockade was achieved with pancuronium bromide $0.15 \mathrm{mg} \cdot \mathrm{kg}^{-1}$ given intravenously. The trachea was intubated either nasally or orally, and intermittent positive pressure ventilation was commenced to maintain $\mathrm{PaCO}_{2}$ in the range $35-40 \mathrm{mmHg}$, with an $\mathrm{FiO}_{2}$ of $0.7-1.0$. During stable general anaesthesia a cannula was inserted into a peripheral artery for measurement of systemic blood pressure, and in ten patients a cannula was inserted transcutaneously into the superior vena cava yia the internal or extemal jugular vein, to monitor central venous pressure (CVP).

Anacsthesia was maintained with a high-dose narcotic technique using either fentanyl ( $n=21)$ or morphine $(n=$ 2). No inhalational agents were given after the induction period and patients were ventilated with an air/oxygen mixture. Following anticoagulation with heparin 300 $\mathrm{lu} \cdot \mathrm{kg}^{-1}$, nonpulsatile CPB was established using a standard roller pump (Cobe Canada Limited, Scarborough, Ontario) and a 0.8 or $1.5 \mathrm{~m}^{2}$ membrane oxygenator (Kolobow Scimed, Minneapolis, Minnesota). The CPB circuit was primed with blood and Plasmalyte (Travenol, Mississauga, Ontario) solution plus mannitol 25 per cent $4 \mathrm{ml} \cdot \mathrm{kg}^{-1}$ to maintain a haematocrit of 30 per cent. CPB flows were $2.4-3.2 \mathrm{~L} \cdot \mathrm{m}^{2}$. Cardioplegia solution consisted of modified Roe's solution with $20 \mathrm{mEq} \cdot \mathrm{L}^{-1}$ of sodium bicarbonate solution in an initial dose of $300 \mathrm{ml}$. $\mathrm{m}^{-1}$ body surface area, and $150 \mathrm{ml} \cdot \mathrm{m}^{-2}$ given at approximately 30-minute intervals. Profound hypothermia with circulatory arrest was used, with mean ( \pm SD) minimum oesophageal and rectal temperatures of $11.3 \pm 1.5^{\circ} \mathrm{C}$ and $18.1 \pm 2.2^{\circ} \mathrm{C}$, respectively. Vasodilators were administered as necessary to assist rewarming during CPB (Table I).

Throughout the study, AFP, MAP and CVP were recorded continuously, CPP was calculated as MAP AFP. MAP, CVP, AFP and CPP were analyzed at five-minute intervals to give mean values during four periods: pre-bypass, cooling bypass, rewarming bypass (immediately after hypothermic circulatory arrest), and post-bypass. During each period oesophageal and rectal
TABLE I Vasodilators administered to assist rewarming during CPB

\begin{tabular}{ll}
\hline & Number of patients \\
\hline Nitroglycerine & 7 \\
Phentolamine & 6 \\
Nitroglycerine + phentolamine & 4 \\
Isoflurane & 1 \\
Jsoflurane + phentolamine & 1 \\
None & 4 \\
\hline
\end{tabular}

temperatures were recorded, and $\mathrm{PaCO}_{2}$ was measured. Arterial blood samples were analyzed at $37^{\circ} \mathrm{C}$ and values of $\mathrm{PaCO}_{2}$ were not corrected for temperture. The duration of each phase of CPB and hypothermic circulatory arrest was noted. Time taken for AFP to return to cooling bypass levels during rewarming bypass was also noted.

To determine whether there was any baseline drift during hypothermia, the performance of the transducer was assessed under hypothermic conditions, both in vitro and in vivo. The transducer was immersed in $10 \mathrm{~cm}$ of water in a water bath at $37^{\circ} \mathrm{C}$, and pressure was recorded as the water bath temperature was reduced to $8^{\circ} \mathrm{C}$. To ensure accuracy under clinical situations, the transducer was laid over the forehead of a patient undergoing hypothermic CPB and PHCA. The transducer was secured in place with a piece of adhesive foam, and any change in baseline was noted as the child underwent hypothermic CPB and PHCA. The forehead was used so that any observed change in pressure would be due to the change in temperature. The temperature of the forehead skin under the foam was also recorded using a standard skin-temperature probe.

\section{Statistical analysis}

Mean values of MAP, CVP, AFP and CPP were compared with their pre-CPB values, repetitive measures analysis of variance and the Student-Newman-Keuls multiple range test. Statistical significance at the level of $\mathbf{p}<0.05$ was accepted. All data are presented as means $\pm \mathrm{SD}$.

\section{Results}

Eighteen male and 5 female infants werc studied. Mean ( $\pm \mathrm{SD}$ ) age and weight were $18.8 \pm 11.3$ weeks and 5.3 $\pm 1.7 \mathrm{~kg}$, respectively. The indications for surgery are shown in Table II. The mean circulatory arrest time was $53.4 \pm 13.9$ minutes, with cooling and rewarming bypass times of $23.8 \pm 9.4$ and $42.4 \pm 23.8$ minutes, respectively. Compared with pre-bypass values, MAP decreased significantly during both phases of bypass (Table III), CVP and AFP were significantly elevated during rewarming $C P B$ ( $p<0.01$ and $<0.005$, respectively). These changes resulted in a significant reduction in CPP $(p<$ 


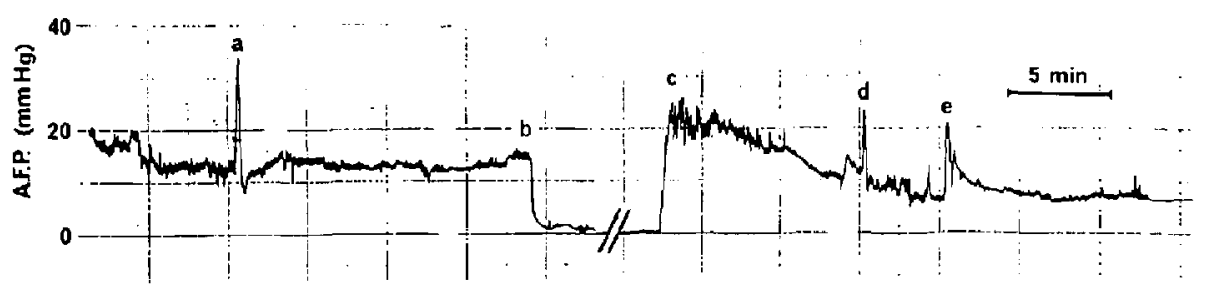

FIGURE Recording of AFP during CPB + PHCA from a representative patient. (a) carotid artery compression at onser of conling CPB; (h) onset of PHCA; (c) reperfusion following PHCA; (d) obstruction of venous return to oxygenator; (c) carotid artery compression at termination of CPB.

\section{TABLE II Type of surgery}

\begin{tabular}{ll}
\hline Procedure & Number of patiens \\
\hline Repair of transposition of & \\
$\quad$ the great arteries & \\
- Mustard repair & 8 \\
- Switch repair & 3 \\
Atrioventriculoseptal defect repair & 5 \\
Ventriculoseptal defect repair & 3 \\
Truncus arteriosus repair & 3 \\
Aurtic valroplasty & 1 \\
\hline
\end{tabular}

0.005 ) during cardiopulmonary bypass. There was no significant change in the $\mathrm{PaCO}_{2}$. The mean duration of elevated AFP (i.e., time to reach a stcady plateau) during rewarming was $16.3 \pm 7.6$ minutes.

A representative recording of AFP from one patien during CPB and profound hypothermic circulatory arrest is shown in the Figure.

The in vitro study of the performance of the Ladd transducer demonstrated that the baseline shifted from $0 \mathrm{mmHg}$ to $3.2 \mathrm{mmHg}$ as the temperature of the water bath was reduced from $37^{\circ} \mathrm{C}$ to $8^{\circ} \mathrm{C}$. In vivo, there was a baseline shift of $+1.0 \mathrm{mmHg}$ as the forehead skin temperature was reduced from $33.2^{\circ} \mathrm{C}$ to $17.7^{\circ} \mathrm{C}$ (corresponding to a rectal temperature of $18.1^{\circ} \mathrm{C}$ ).

\section{Discussion}

This study demonstrates that cercbral perfusion pressure decreases significantly during cardiopulmonary bypass in infants undergoing profound bypothermic circulatory arrest. During cooling bypass this decrease is primarily due to a relative hypotension, with insignificant changes in AFP. On reperfusion after circulatory arrest, it is due to both a relative hypotension and a significant increase in anterior fontanel (or intracranial pressure).

In adults, Lundar et al.$^{1-4}$ have used an epidural transducer to measure ICP during hypothermic CPB. As in our study, ICP was unchanged at the onset of CPB, and CPP was reduced rapidly to less than $30 \mathrm{mHg}$, secondary to a decrease in MAP, in 88 per cent of patients. ' ICP remained stable during established $\mathrm{CPB}$, except where there were fiuctuations in CVP caused by the surgical procedure or obstruction of the venous blood flow to the extracorporeal oxygenator. At termination of CPB there were similar increases in ICP secondary to increased CVP.

The increase in AFP seen in our study is most likely multifactorial. It may merely reflect increased CVP (Table III). Four patients who had CVP monitoring underwent Mustard repair for transposition of the great arteries, in which one would expect CVP to be raised during rewarming CPB. Excluding these four infants,

TABLE IIf Pressures during each phase of CPB $\left(\mathrm{mmH}_{\mathrm{g}}\right)$

\begin{tabular}{|c|c|c|c|c|}
\hline & Pre-CPB & $\begin{array}{l}\text { Cooling } \\
\text { CPB }\end{array}$ & $\begin{array}{l}\text { Rewarming } \\
\text { CPB }\end{array}$ & $\begin{array}{l}\text { Post- } \\
C P B\end{array}$ \\
\hline Mean systemic artcrial blood pressurc & $57.0 \pm 11.8$ & $38.8^{*} \pm 8.4$ & $45.8^{*} \pm 8.9$ & $54.4 \pm 8.0$ \\
\hline Central venous pressure & $8.0 \pm 5.8$ & $8.4 \pm 7.0$ & $17.2^{\dagger} \pm 7.4$ & $12.4=3.7$ \\
\hline Anterior fontanel pressure & $10.6 \pm 2.9$ & $11.6 \pm 4.3$ & $18.3^{*} \pm 6.4$ & $8.6 \pm 3.2$ \\
\hline Ccrebral perfusion pressure & $46.5=12.3$ & $27.3^{*}=11.0$ & $27.5^{*} \pm 10.6$ & $45.6=7.3$ \\
\hline $\mathrm{PaCO}_{2}(\mathrm{mmHg})$ & $34.5=8.5$ & $38.6 \pm 8.7$ & $37.5=9.7$ & $33.8 \pm 6.5$ \\
\hline
\end{tabular}

Data are mean values $( \pm S \mathrm{SD}$ )

${ }^{*} p<0.005$ (compared with pre $-\mathrm{CPB}$ )

$t_{p}<0.01$ (compared with pre-CPB). 
mean CVP was $14.9 \pm 5.1 \mathrm{mmHg}$ during rewarming, which is still significantly greater than pre-CPB values $(\mathrm{p}$ $<0.05$ ). However, in none of the patients did the duration of increase in AFP parallel changes in CVP.

The increased AFP may be a temperature-related hyperaemia. Raised ICP has been reported during slow rewarming in conscious patients who have been couled to body temperatures of $29-33^{\circ} \mathrm{C}$ for periods of up to 198 hours. This increase has been attributed to increases in cerebral interstitial fluid volume and intracranial blood volume. ${ }^{8}$ Furthermore, after a period of vascular arrest all tissues show increased blood flow, and such a reactive hyperaemia is more marked in the brain than elsewhere." This "hyperperfusion syndrome" is probably initiated by abnormal accumulation of cerebral metabolities. However, during PHCA one would expect a marked decrease in cerebral metabolic rate. While only minimal accumulation of metabolites would be anticipated, it may be sufficient to cause short-lived cerebral oedema. The usc of intravenous nitroglycerine during rewarming CPB may also have affected ICP. ${ }^{10}$ Similarly, inhalational agents, including isoflurane, increase cerebral blood low (CBF) and consequently ICP." Cerebral blood flew is also markedly increased by haemodilution, ${ }^{12}$ and sudden reperfusion with a perfusate of low haematocrit may be a factor in raised ICP. Such changes might be expected to be offset by an increase in blood viscosity due to profoundly low temperatures at the time of reperfusion. Reasons for the abserved increase in ICP may, therefore, be multifactorial.

Calculations of CPP alone do not necessarily give an accurate indication of the adequacy of cerebral perfusion. CBP depends on other factors, of which the most important is autoregulation of the cerebral circulation. Reductions of CPP, below the lower limit of autoregulation (LLAR), may result in cerebral hypoxia and neurological deficit. Studies of CBF in infants undergoing hypothermic CPB have not been performed, and the LLAR has not been established in this group of patients. However, studies in adults during CPB have produced conflicting estimates of LLAR. Govier et al. ${ }^{13}$ have demonstrated that LLAR appears to be as low as MAP $20-30 \mathrm{mmHg}$, while Henriksen and coworkers ${ }^{14}$ have shown a decrease in CBF related to decrease in MAP below $55 \mathrm{mmHg}$. CBF remains responsive to changes in arterial $\mathrm{PCO}_{2}$ during hypothermic $\mathrm{CPB},{ }^{15}$ and differences in management of $\mathrm{CO}_{2}$ homeostasis may be responsible for these conflicting results. As in the study by Govier et $a l^{13}$ we measured $\mathrm{PCO}_{2}$ values without temperature correction, whereas Henriksen et al. ${ }^{14}$ used temperaturecorrected values, which have been shown to result in higher CBF values. ${ }^{16.17}$

It is possible, therefore, that LLAR is also extended in infants, and this phenomenon may protect the brain from the risk of cerebral ischaemia. In addition, reductions in CBF may be tolerated during hypothermic CPB because of a concomitant reduction in cerebral oxygen utilization. In adults under these circumstances, Murkin et al.$^{16}$ have demonstrated a cerebral oxygen supply in excess of cerebral oxygen demand. The effects of rapid cooling and the low temperatures at the onset of reperfusion after PHCA may protect the brain from the observed reductions in CPP.

A problem associated with some studies using the Ladd transducer has been the method of fixation, and several techniques have been recommended. A very good correlation between measurements of AFP from the Ladd transducer, and from simultaneous measurements of cerebrospinal fluid pressurc at ventriculostomy or lumbar puncture has been demonstrated by Hill and Volpe. ${ }^{6}$ Using their method we have shown a clinically insignificant baseline drift of $1.0 \mathrm{mmHg}$ during hypothermia to a mean rectal temperature of $18.1^{\circ} \mathrm{C}$.

In conclusion, we have demonstrated that in infants undergoing $\mathrm{CPB}$ there are significant decreases in cerebral perfusion pressure. These are associated with a relative hypotension and, during repcrfusion after profound hypothermic arrest, a significant increase in anterior fontanel pressure. Further studies of cerebral blood flow and cerebral metabolism during $\mathrm{CPB}$ and PHCA in children are indicated.

\section{Acknowledgements}

This paper was prepared with the assistance of Ms. Terri Cain and the Medical Publications Department, The Hospital for Sick Children, Toronto.

\section{References}

1 Lundar T, Froysaker $T$, Nornes $H$, Lillaaden L. Aspects of cerebral perfusion in open-heart surgery. Scand J Thor Cardiovasc Surg 1982; 16: 217-22.

2 Lundar $T$, Froysuker $T$, Nornes $H$. The clinical significance of changes in ecrebral perfusion pressurc during open-heart surgery. Seand J Thor Cardiovase Surg 1983; 17: 163-9.

3 Lundar T, Froysaker T, Lindegaard K-F et al. Some observations on cerebral perfusion during cardiepulmonary bypass. Ann Thor Surg 1985; 39: 318-23.

4 Lundar $T$, Lindegausd K-F, Froysuker T, Aaslid R, Wiberg $J$. Nornes $H$. Cerebral perfusion during nonpulsatile cardiopulmonary bypass. An Thor Surg 1985; 40: 144-50.

5 Vidyasagar D, Raju TNK. A simple non-invusjve technique of measuring intracranial pressure in the newbom. Pediatrics 1977; 59: 957-61.

6 Hill A, Volpe $J J$. Measurement of intracranial pressure using the Ladd intracranial pressure monitor. Pediatrics 1981; 98: 974-6. 
7 Mann WN (ed). Coneybeare's textbook of medicine, 16th edition. Edinburgh, Churchill Livingstone, 1975, p 470.

8 Boch $M$. Cerebral aspects of rewarming following hypothermia: signiticance for the management of severe cranio-cerebral injury and acute pyrexia. Brain 1967; 90 : $769-84$

9 Lassen NA. The luxury perfusion syndrome and its possible relation to acute metabolic acidosis localised within the brain. Lancet 1966; 2: 1113-5.

10 Ghani GA, Sung YF, Weinstein MS, Tindall GT, Fleischer $A S$. The effects of nitroglycerine on the intracranial pressure and volume pressure response. J Neurosurg 1983; 58: 562-5

11 Sulken EH, Milde HJ, Michenfelder JD, Tinker JH. The non-linear responses of cerebral metabolism to low concentrations of halothane, enflurane, isoflurane and thiopental. Anesthesiology 1977; 46: 28-34.

12 Henriksen L, Paulson OB, Smith RJ. Cerebral blood flow following normovolemic hemodilution in patients with high hematocrit. Ann Neurol 1981;9;454.

13 Govier AV, Reves JG, Mckay RD et al. Factors and their influence on regional cerebral blood flow during nonpulsatile cardiopulmonary bypass. Anת Thor Surg 1984; 38: $592-600$.

14 Henriksen L, Hjelms E. Lindeburgh T. Brain hyperperfusion during cardiac operations. J Thorac Cardiovase Surg 1983; 86: 202-8.

15 Prough DS. Stump DA. Roy RC et al. Response of cerebral blood flow to changes in carbon dioxide tension during hypothcrmic eardiopulmonary bypass. Anesthesiology 1986; 64: 576-81.

16 Murkin JM, Farrar JK, Tweed WA, Guiraudon $G$, McKenzie FN. Relationship between cerebral blood flow and oxygen consumption during high-dose narcotic anesthesia for cardiac surgery. Anesthesiology 1985; 63: A44.

17 Prough DS, Stump DA, Rogers AT, Gravlee GP, Angeri $K C$. Nitroprusside decreases cerebral blood flow during cardiopulmonary bypass. Anesthesiology 1986; 65: Al3.

\section{Résumé}

Le tramstucteur de Ladd a ćté utilisé pour mesurer la pression de la fontanelle antérieure chez 23 nourrissons sous circulation extra-corporelle et arrêt circulatoire en hypothermie profonde pour correction chirurgicale de maladie cardiaque congénitale. Des températures aesophagiennes et rectales minimates moyennes ( $\pm S D)$ de $11.3 \pm 1.5^{\circ} \mathrm{C}$ et de $18.1 \pm 2.2^{\circ} \mathrm{C}$ respectivement. ont été atteintes avec une durée moyenne d"arrêt de $53.4 \pm 13.9$ minutes. Pendant ta circulation extra-corporelle de reperfusion. post-arrèt circulatoire. la pression moyenne de la fontanelle

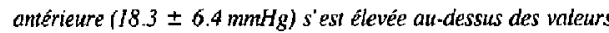
de base pré-circulation extra-corporelle $(10.6 \pm 2.9 \mathrm{mmHg})$ $(p<0.005)$. La pression artérielle moyenne a diminué de jaçon significative sous les valeurs pré-circulation extra-corporelle $(57.0 \pm 11.8 \mathrm{mmHg})$ duranr le refroidissement $(38.8 \pm 8.4$ $\mathrm{mmHg}$ let le réchouffement $(45.8 \pm 8.9 \mathrm{mmhg})(p<0.005)$. Ces changemenus étaient associês d̀ une diminution significative de la pression de perfusion cérébrale au refroidissememt $(27.3 \pm$ $11.0 \mathrm{mmHg}$ ) et au réchauffement $(27.5 \pm 10.6 \mathrm{mmHg})$ en comparaison aux valeurs de base obtenues $(46.5 \pm 12.3 \mathrm{mmHg}$ ) $(p<0.005)$. Les données démontren des diminutions signifi. catives, quaique iransitaires, de la pression de perfusion céré. brale durant le refroidissement et le réchauffement sous circula. tion extra-corporelle. 